\title{
ASSESSING PUBLIC OPINIONS ON THE QUALITY OF PASSPORT SERVICE
}

\author{
Ananda Prasetia*, Putu Abiyasa Agus \\ Undiknas Graduate School, Bali, Indonesia \\ *E-mail: anandaprass@gmail.com
}

\begin{abstract}
The purpose of this research is to find out (1) the quality of passport issuance service in Class I Immigration Office TPI Denpasar, (2) the supporting factors and the obstacle factors that affect the services, and also (3) the strategy that used to minimize the complaint and to increase the service quality. This research used the qualitative-descriptive research with data collecting technique through observation, interview by using the purposive random sampling technique, and documentation. 50 (fifty) informants were taken in this research. They were people who applied for passports and some of them were structural officers. This research adopted the research concept by Parasuraman, Berry and Zeithaml consisting of five dimensions: Tangibles, Responsibility, Responsiveness, Assurance, and Empathy to measure the service quality. This result shows that (1) there are some indicators that not working with public expectations, (2) the supporting factors are all the elements are commit to providing the excellent service, comfortable waiting room, free internet, free drinks, special line for human rights, having professional human resources, Innovating through Passport on the Spot (POTS), utilizing the social media as the communication and information dissemination, and also simplification for registration using the APAPO application. And for the obstacle factors are lacks of human resources and systemic disruption often occurs internally or externally, they do not have the notification system for automatically passport application, and also they need for rejuvenation of device due to they are already more than 5 (five) years, (3) the service strategies are formulated: Face-to-face service strategy to the public, extending service period, coordination, dissemination current information, and reducing queue quota.
\end{abstract}

\section{KEY WORDS}

Public service, quality service, passport service, immigration office, public satisfaction.

As a civil servant is to serve the public according to the Act number 5, 2014 concerning about civil servant officers. In order to implement the function, civil servant officers, they have to be a planner, executor, and inspector for the government and national development through the policy implementation and professional public services, free from any political intervention, and also clear from any form of corruption.

According to the Act number 25, 2009, stated that by the means of public service is an activity or a sequence of activity in order to give a fulfillment of service in accordance with the regulations for all citizens to gain goods and services from the public service operator. The output is the public service quality that becomes a strategic issue as the people is demanded the good quality service. People are likely to have high expectations towards the public service, that is why some people love to talk about it. People want what people needs. If it is not in line with their expectations, then it can be considered as a low-quality service.

Whether it fits or not to the people's expectations about good quality in public service is not only defined by the provider, but it also defined by the perception or public opinion as the user. It is mandatory for the government as the provider to give the improvement to minimize the complaint and to give the satisfaction for the people.

Directorate General of Immigration (Ditjenim) is a part of Ministry of Law and Human Rights of Indonesia has main tasks to perform the policy and technical standardization in immigration services. Yasonna Laoly as Minister of Law and Human Rights of Indonesia expected that in 2019 (Ditjenim) has to restructure the Immigration Management Information System/SIMKIM, Dylan (2019). 
According to the Act number 6, 2011, concerning about the immigration, by the definition of SIMKIM is an information and communication technology that used to gather, process and to present the information to support the operational, management, and decision-making process to implement the immigration functions. According to the Director of Immigration Letter number: IMI.7-TI.01.02-0869, on May 10, 2019, concerning about the deactivation notice of SIMKIM version 1, then for this current time all the immigration services are using the newest version of SIMKIM (2.0) to open service for all Indonesian Citizens in the matter of passport issuance and for the foreign nationals as regards to temporal/permanent stay permits since May 17, 2019. Besides that, in order to support the acceleration of service in passport issuance, the Ditjenim has made an application called APAPO (an online queue registration application). It is expected to solve the long queue problems, so public can ease the queue registration and to match with their own schedule.

The pre-research was conducted on June, 2019, in the Class I Immigration Office Denpasar (Kanim Denpasar), there was a problem occurred in issuing the passport; people did not get the service assurance due to the most frequently application maintenance service. The service assurance is one of the foundations of governmental administration and licensing must be noticed, Ratminto and Winarsih (2006). The services and solutions must be solid, so people can have the clear information and to avoid the confusion in the process of passport issuance.

System maintenance that frequently happened is affected the people. The service assurance in issuing the passport and the inaccurate time completion (three days after the payment) or it could be 5 (five) days or even worst.

The second problem is lacks of human resources on the Immigration Traffic (LANTASKIM). Assigning the officers on the other sections outside the Class I Immigration Office Denpasar (Denpasar and Badung Public Service Mall) is definitely affected the number of officers to serve the passport issuance. This is likely causing the short number of officers that affected the service quality.

The third problem is the number of online queues versus the number of human resources. The high demand on the passport issuance has been responded by Directorate General of Immigration by issuing the official letter number: IMI-UM.01.01-1958 on May 8, 2019 concerning about upgrading the passport application services on the Immigration Office by enhancing the online queues number as much as 50 (fifty) applications. So on a daily basis at Kanim Denpasar takes up to 250 applications. This number excludes the priority line for breastfeeding mothers, senior citizens, pregnant women, children under 5 years old, and people with disabilities will be given the walk-in facility. If the number of queues and the number of human resources is not balance, then that will not be optimal for services.

\section{LITERATURE REVIEW}

Service according to the Indonesia Great Dictionary is an effort to help or to prepare or to manage something that someone needs to. Then according to Harbani Pasolong (2013) in his public administration book defines that service is an activity of someone, group, and/ or organization whether it is direct or indirect to fulfill the needs.

There are several foundations in implementing the government services and licensing that need to pay more attention, according to Ratminto and Winarsih (2006) they are: an empathy with the customer, procedures limitation, the clarity of service procedures, schedule certainty and service duration, minimize the forms, clarity of authority, extend the permit validity period, the clarity of rights and obligations of providers and customers, and the effectivity of complaint handling.

According to Noverman Duadji (2013), public management is service governance that has roots such as planning, organizing, implementing, and evaluating as a feedback mechanism to innovate the service performed by public agents in mobilizing the source (goal) and source allocation (public interest adaptation) in order to provide the best services/goods to the people. 
Public policy is a government instrument, not only it related with public servants, but also a true governance that manage the public resources. According to Bridgeman and Davis (2004) in Edi Suharto (2007) stated that the public policy consists at least 3 (three) dimensions that connect to each other:

- Public policy as a goal;

- Public policy as a legal act;

- Public policy as a hypothesis.

Reinventing local government initiated by David Osborne and Ted Gaebler to find out solutions in the context of public service optimization. There are 10 (ten) principals: catalyst government, people's government, competitive government, government by mission, targetoriented government, customer-oriented government, entrepreneurial government, anticipatory government, decentralization government, and market-oriented government.

The focus of reinventing local government for this current time is emphasized on the continuous of management capacity enhancement to increase the quality of service performance for local government. The innovations by local government determines how the local government gain the input, and then process it, so it can produce the suitable output of the people's needs.

In accordance with the President Instruction number 3, 2003, about the policy and national strategies development of E-Government stated that the government must as soon as possible to carry out the E-Government transformation process. Through this process, the government can optimize the utilization of advanced information technology to eliminate the barriers of organization bureaucracy, and also to establish the management network system and working process which allows government agencies work in integrating way to simplify the access to all information and public services that government must provide. Therefore, all the state agencies, society, business world and all the stakeholders can access it optimally at any time.

The public service quality according to Evans and Lindsay (2000) is a dynamic condition related to the product, service, human, process, and environment that fulfill or beyond expectations. It also can be defined as providing the good services as an effort to create the public satisfaction.

Knowing the service quality that held by government is an important thing because it gives the benefit to the organization. According to Zeithaml, in Pasolong (2011), in order to find out the service quality there are 5 (five) dimensions: Tangibles, Reliability, Responsiveness, Assurance, and Empathy.

The service quality according to Albrecht and Zemke (1990), is a result from interactions of 4 (four) aspects, they are: service system, human resources that provide the service, strategy, and customers. All of them can be seen in triangle of public service below.

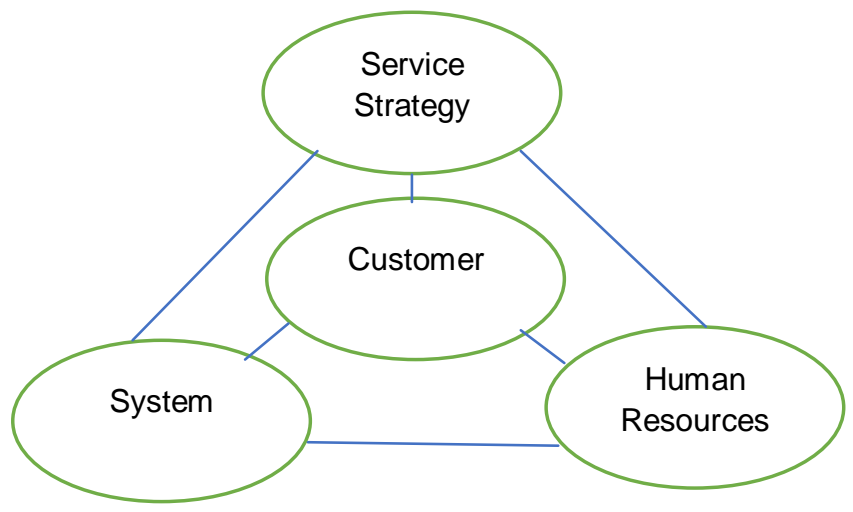

Figure 1 - Public Service Triangle

According to Tjiptono (2012) there are several factors used to increase the quality of service such as: to identify the main determinant of service quality; to manage the customer 
expectations; to manage the service quality testimony; to educate the consumer about the service; to maintain the quality culture.

\section{METHODS OF RESEARCH}

The research location was at Class I Immigration Office TPI Denpasar. This was a descriptive research with qualitative approach and the data source that was used in this research are primary data and secondary data. The primary data were obtained by observation and interview with the informant. And then, the secondary data were obtained from the graphic documents such as tables, notes, text messages, photos, etc. Arikunto (2010)

This research used semi-standard interview type (semi standardized). The informants in this research were chosen with purposive sampling technique which means that the sample collection technique is for specific purposes, Sugiyono (2007). They are Sub Section Chief of Immigration Inspection, Sub Section Chief of Travel Document Service, Section Chief of Immigration Communication \& Information Technology, Section Chief of Immigrating Traffic, and 50 (fifty) samples of public society that applied for passports in Class I Immigration Office TPI Denpasar.

The active participation type was used as the data collection technique. It means the writer was directly involved in the passport issuance services. Then, Sugiyono's circular analysis was used in this research by divided into several phases; descriptive phase, reduction phase, and selection phase.

\section{RESULTS AND DISCUSSION}

The service quality according to Parasuraman (1985) is a measure of how good a service to match with customers. In order to find out the quality of passport issuance service, it can be measured through the service dimension that is known by the term of SERVQUAL (Service Quality) as follows:

Tangible Dimension. According to the theory by Kasmir (2006) about characteristics of public service, he stated that the assessment of passport issuance service quality such as infrastructures availability whether it is equipment or facility that match to the public expectations.

To increase the service quality in terms of convenience and simplicity while using the provided facility, it requires rearrangement especially the customer service position that is too small and near the doorway, then it would make more crowded for the applicants when they want to take queue number or just asking for information. Other facilities are the availability of ATM machine or EDC (Electronic Data Capture) machine as cashless payment method. So, it is expected that the people will feel convenient about what payment method they want to choose.

Next is in terms of appearance. According to Sugiyanto (1999), appearance is a form of self-image comes out from someone, and also as a communication between one person to another. Based on the research that has been done, the officers look has matched with the regulation. This thing is in line with the theory by Kasmir (2005) about service standards, he stated that an officer must be neat and clean. Wearing a uniform is also to show the organization identity, the compactness, and to give professional impression within the service.

Third is the officer disciplinary in serving the public. According to Sastrohadiwiryo (2003), work discipline is a respect manner, to appreciate, to loyal and to obey the regulations, and also to perform it and not to avoid the sanctions if he/she violates the duty and the authority. The entire officer at Kanim Denpasar has committed to give the best service that they have to the public. But it only a few problems such as system troubleshooting that prevent the maximum result.

Reliability Dimension. From the results of the research, first of all in term of certainty for providing services, the officer asks for requirements in accordance with the applicable 
provisions. A passport applicant can also check through the website or come in person. However, due to systemic disruptions, the certainty of the officer in providing services becomes uncertain. For example, if the payment receipt cannot be issued, public must wait until the system is normal and come back to Kanim to take payment receipt.

Then the opening time for service is also already conformed to the principle in organizing government services according to Ratminto and Winarsih (2006) stating that service schedule and duration must be certain, thus the public has a clear picture and is not restless. Furthermore, related to the calling of queue numbers is also already conformed and in sequence, no applicants without queue numbers.

Secondly, in terms of passport completion, public still do not get any certainty. When referring to the principle of organizing public services in accordance with Law Number 25 of 2009 Article 4 in terms of timeliness, including the accuracy of passport completion service, then Denpasar Immigration Office has not been able to fulfill those becoming people's basic needs.

In public management theory, it is stated that one of the characteristics of public management itself is fulfillment of basic need. This means that the timeliness to passport completion schedule is the main point that must be fulfilled by the Denpasar Immigration Office as public service organizer.

In accordance with the existing standard operating procedures, to make a passport the applicant should only come twice. The first is at the examination of file, photograph and interviews. The second is when taking the passport. But in reality, when taking a photo and conducting an interview there are some applicants whose payment receipts cannot be issued due to disruption. Then when taking the passport as scheduled, the passport has not yet completed. Of course, this makes the passport applicant wait again.

In fact, the officer has estimated 5 (five) working days (longer than it should). What the passport applicant desired is if the passport completion is delayed, they should contact them through a number already existed on the file or via email.

In terms of service easiness and speed, it can be seen from the applicant comes and takes a queue number until he/s the takes a photo, interview and the payment receipt is issued, all of them can be completed within a period of around 1 (one) to 2 (two) hours depending on the rush of the passport applicant and the system condition at that time. This means that in terms of speed Denpasar Immigration Office has fulfilled the requirements according to Kashmir theory (2005) concerning service speed. For completion period of more than the existing operating procedures, the officer estimates around 5 (five) working days to take the passport. However, some passport applicants also get information that some passports are completed more than the schedule already determined, some within 5 (five) or 10 (ten) days, or even more.

Thirdly, when seen from standard service, the passport applicant feel that the application route provided by the officer is already conformed to the existing provisions. When the applicant comes, he/she is welcomed by a service ambassador officer. At that time the officer also asks the purposed of the applicant. After that, the service ambassador officer gives directions to take a queue number before checking files. This is also in line with the principle of organizing government and licensing services according to Ruminto and Winarsih (2006) stating that the service procedures should be designed as simple as possible and communicated to public using the service.

Responsiveness Dimension. Firstly, in terms of information, a passport applicant has an opinion that the delivery of information related to the standard operating procedures is already submitted clearly to the public in accordance with the applicable provisions. This is in line with those said by Moenir (2005), namely in order for the service to be able to satisfy people or groups, then it should fulfill the criteria for delivering something related to what should be accepted by the public.

Before checking a file, the service ambassador provides an explanation regarding the standard operating procedures or procedures for applying a passport. With such information, of course it is very helpful for the passport applicant to be more careful to minimize the 
rejection of the application. When constrained by the system, the officer also provides information directly to the applicant through microphones, thus it can be heard by all visitors.

Analysis of the author in terms of the officer's response in carrying out services, it can be said to be already good. The officer is not discriminatory in providing services. The officer quickly responds to those becoming the need of the passport applicant, such as requirements for making a passport, difficulties in registering on the application, questions concerning queue number, and also questions sent via social media such as Instagram and Facebook are responded properly and fast. The officer is also active in asking the passport applicant who has not been served, and updating the page on the social media when systemic disruption occurs.

Thirdly, in terms the officer's ability to respond to complaints. At the time the author conducted an interview with passport applicants, they complained about the application that frequently has disruption, there are also some applicants who had made payment but not detected by the system. This, of course, results in delays in the passport completion. When disruption occurs, the officer has tried to provide explanation to the applicant by apoligizing in person, but the passport applicant desires time assurance for taking the passport as directed by the officer. This is important because the applicant has been waiting for a long time while the officer cannot give certainty. At the same time, the officer also asks for the mobile phone number of the passport applicants, but most of them said that the officer does not provide any information in the form of SMS.

The presence of innovation, namely the use of SIMKIM Version 2.0 should be able to increase the capacity of sustainable management, thus the local government performance to be better in presenting public services in accordance with reinventing local government theory. The existence of problems as explained above indicates that the output expected by the public has not conformed to the needs.

Assurance Dimension. Firstly, in terms of costs, the officer always explains the cost nominal to be paid after printing the payment receipt. Then the officer ensures that the amount paid conforms to the applicable regulation; to make a new passport or replace a passport, it is only imposed a cost of IDR 350,000 no less and no more.

Secondly, in terms of passport completion, from the interviews already conducted, most of the passport applicants do not get any guarantee of passport completion. Most passport are completed more than 3 (three) working days. According to Evans and Lindsay (2000) the services provided by Denpasar Immigration Office have not fulfilled the expectation of the people because they cannot achieve the objectives in accordance with the existing provision.

Based on the results of field studies, for passport applicants who are not in a hurry to use the passport to travel, it is not a problem, but on the other hand for the applicants who need it in a closer time, especially for very urgent necessity, it will be a problem. People's expectation to Denpasar Immigration Office is to immediately make improvement due to passport applicants feel harmed by the time.

Thirdly, guarantee in terms of easiness for registration process through APAPO (Online Passport Registration Queue) application. People think that it is easy to use the application. This is very different from the previous year, now the applicant can make registration anywhere and at any time provided that he/she uses internet connection and queue quota is available. This has conformed to the concept of Indrajit (2002) concerning E-Government that facilitates the people using information technology. But there are also some passport applicants who cannot register because NIK (Population Registration Number) data is not detected by the system.

Empathy Dimension. Firstly, in terms of hospitality and courtesy. According to Kashmir (2006) and Moenir in Tangkilisan (2005) hospitality is an important point needed in the service process. If the officer serves friendly, the passport applicant is happy and gives a good assessment to the organization. Not only hospitality, courtesy is also needed in providing quality service. From the research already conducted, most passport applicants have an opinion that the officer is already friendly and courteous in providing services, 
especially in the photo section. However, there are also applicants who have opinion that in other sections such as file inspection, the officer is less friendly.

Secondly, the officer prioritizes more the interest of the passport applicants thant personal interests. In this case the officer always works earnestly and professionally for the public interests. This is according to the characteristics of public service management according to Noverman Duadji (2013) and fulfills the principle of organizing public services in accordance with Law Number 25 of 2009 concerning Public Service. From the results of observation and interview already conducted, most officers are not busy playing gadgets or handphone or having a chat with their partners when servicing the passport applicants. This shows that the passport applicant is the main priority in providing services.

Thirdly, regarding the priority route. Priority route is a special route given to the passport applicant in the category of pregnant woman, breastfeeding mothers, elders, children under 5 (five) years and disabled persons. This priority route is important for people who have special needs. Based on the reinventing local government theory initiated by David Osborne and Ted Gaebler, the government is oriented towards customers. This means that the government must learn from the business sector to focus and pay attention to customers. Otherwise, the customers are not satisfied with the services provided.

Most people do not feel that their interests are disturbed, but there are also those who believe that the services provided should not be differentiated between ordinary and prioritized applicants, thus they all of them get the same rights.

The supporting factors for passport issuance in the Class I Immigration Office TPI Denpasar are:

- All elements are committed to providing excellent service, by signing service standards by the Ombudsman of the Republic of Indonesia in the territory of Bali and corroborating integrity by the Head of the Regional Office of Law and Human Rights in Bali;

- Having adequate facilities;

- Having professional HR;

- Innovating through Passport on the Spot (POTS) service;

- Utilizing social media as a means for communication and information dissemination;

- Easiness for use of APAPO application to break queues.

Then the obstacle factors in the passport issuance service are:

- Systemic disruption often occurs;

- Do not have the notification system for automatically passport application;

- The need for rejuvenation of device due to they are already more than 5 (five) years;

- Lack of HR.

Strategy is an idea and planning within a certain period of time to achieve objectives effectively. In every activity program, the objectives of the strategy are not only as guidance, but also they must demonstrate their operational tactics. According to Gregory (2004), strategy is a coordinating factor, demanding principle, main idea and thinking behind tactic programs.

Based on the results of field observation, Denpasar Immigration Office always seeks to provide the best for the people in accordance with the motto already agreed, namely from the heart serves sincerely. This means that people who serve are those who serve sincerely and selflessly. That is a commitment that must be carried out. In providing passport publishing services, there are constraints as explained previously. In providing services for passport issuance, there are constraints already explained before. To anticipate those matters the following service strategies are formulated:

- Face to face to the public;

- Extending service period;

- Coordinating with other sections;

- Dissemination current information;

- Reducing queue quota. 


\section{CONCLUSION}

This research can provide a picture regarding the people's opinion when applying for a passport in Denpasar already uses its latest application, namely the SIMKIM version 2.0. This opinion can be used as a benchmark for Denpasar Immigration Office to improve its service quality to become better.

From the results of the study of the 5 (five) dimensions of service quality, it can be concluded that the passport issuance service in Denpasar Immigration Office is not yet fully qualified due to there are some indicators that have not been fulfilled.

Public services provided to public cannot be separated from 4 (four) aspects, namely system, human resources, customers and service strategies. This is according to Alorecht and Zemke (1990). From the results of the research, to produce quality service, at least 5 (five) aspects are required, namely system, human resources, customers (in this case passport applicants), strategy and evaluation. Evaluation in this case is required as a consideration material for decision maker in determining alternatives for the next policy.

Based on the conclusion, then the following suggestions can be given:

- Passing a Memorandum of Understanding (MoU) with a perception bank to increase non-cash payment facilities;

- Evaluating the use of SIMKIM application Version 2.0 and reporting it to the Directorate General of Immigration as suggestion material;

- Immediately running the notice system on passport application stages such as the previous SIMKIM application using SMS gateway;

- Revising the budget for planning the replacement of devices in the following year;

- If within 2 (two) to 3 (three) consecutive days the application is not normal it is better to reduce the queue quota, thus the work does not pile up or the service is done first until the system is normal again;

- Adding HR to accelerate the service.

For further research in the further it should not only be done in the field of passport issuance services, because the Denpasar Immigration Office has other immigration services such as services for Foreign Citizens related to stay permit and immigration status and immigration services in the field of immigration action, thus it can represent quality service of Depansar Immigration Office as a whole.

\section{REFERENCES}

1. Arikunto, S. (2010). Prosedur Penelitian Suatu Pendekatan Praktik. Jakarta: Rineka Cipta.

2. Anggadini, Sri Dewi. (2013). Analisis Sistem Informasi Manajemen Berbasis Komputer dalam Proses Pengambilan Keputusan. Jurnal Ekonomi. Vol. 11(2): 176-186.

3. Barata, Atep Adya. (2017). Dasar-dasar Pelayanan Prima. Jakarta: PT. Elex Media Komputindo.

4. Berg, Bruce L. (2007). Qualitative Research Methods for The Social Sciences. Boston: Pearson Education, Inc.

5. Bintari, Suciani Cahya, Nandang Safudin Zenju, Irma Purnamasari. (2017). Kualitas Pelayanan Pembuatan Paspor di Kantor Imigrasi Kelas I Kota Bogor. Jurnal Governisasi. Vol. 3 (1). E-ISSN: $2549-7138$.

6. David, Fred R. (2005). Manajemen Strategis: Konsep. Jakarta: Salemba Empat.

7. David, Fred R. (2012). Strategic Management Concepts \& Cases. Pearson Academic $14^{\text {th }}$ edition.

8. Darmawanti, Fitria, Sarwono, and Abdul Wachid. (2015). Persepsi Pemohon Paspor terhadap Reformasi Layanan One Stop Service (Studi pada Kantor Imigrasi Kelas I Kota Malang). Jurnal Administrasi Publik (JAP). Vol. 3 (10): 1782-1786

9. Duadji, Noverman. (2013). Manajemen Pelayanan Publik (Wacana Konsep, Teori and Problema Pelayanan Publik). Bandar Lampung: Universitas Lampung.

10. Evan and Lindsay. (2000). Membangun Kepuasan. Jakarta: Rineka Cipta. 
11. Firdausy, Attina. (2018). Kualitas Pelayanan Kantor Imigrasi Kelas I Khusus Surabaya. Jurnal Kebijakan and Manajemen Publik. Vol. 6 (2): ISSN 2303-341X.

12. Gelinas, Ulrich and Richard B. Dull. 2012. Accounting Information System. Canada: Cengage Learning.

13. Harbani, Pasolong. (2013). Teori Administrati Publik. Bandung: Alfabeta.

14. Indrajit, Richardus Eko. (2002). Membangun Aplikasi E-Government. Jakarta: PT Elek Media Komputindo.

15. Instruksi Presiden Republik Indonesia Nomor 3 Tahun 2003 tentang Kebijakan and Strategi Nasional Pengembangan Electronic Government.

16. Kasmir. (2005). Etika Customer Service. Jakarta: Raja Grafindo Persada.

17. Magdalena, Lydia, Ambar Harsono, Sugih Arijanto. (2014). Analisis Kualitas Pembuatan Paspor di Kantor Imigrasi Kelas I Bandung dengan Menggunakan Metode Service Quality. Jurnal Onlinr Institut Teknologi Nasional. ISSN: 2338-5081.

18. Moenir. (2005). The Managemenr of Conflict: Interpretations and Interest in Comperativee Perspective, Yale University Press.

19. Nurmalasyiah. (2016). Teknologi Informasi Percepatan Pelayanan Publik Pembuatan Paspor Pada Kantor Imigrasi. Jurnal IImiah Administrasi Publik. Vol. 2(4): 195-197.

20. Osborne, David and Ted Gaebler. (1996). Mewirausahakan Birokrasi, terj. Abdul Rasyid. Jakarta: Pustaka Binaman Pressindo.

21. Osborne, David and Peter Plastrik. (2000). Memangkas Birokrasi: Lima Strategi Menuju Pemerintahan Wirausaha, terj. Abdul Rasyid and Ramelan. Jakarta: PPM.

22. Pasolong, Harbani. (2011). Teori Administrasi Publik Cetakan Ketiga. Bandung: CV. Alfabeta.

23. Purnomo, Agung Sulistyo. (2018). Citizen Oriented Service Delivery and Innovation (A Case Study of Passport Office in Indonesia). Jurnal Ekonomi and Kebijakan Publik. Vol. 9(1): 15-27.

24. Peraturan Pemerintah Nomor 31 Tahun 2013 tentang Peraturan Pelaksanaan UndangUndang Nomor 6 Tahun 2011 tentang Keimigrasian.

25. Rachman, Dylan Aprialdo. (2019). https://nasional.kompas.com

26. Ramseook, Praba Munhumun, Soolakshna D Lukea Bhiwajee, Perunjodi Naidoo. (2010). Service Quality in the Public Service. International Journal of Management and Marketing Research. Vol. 3 (1).

27. Ratminto, and Atik Septi Winarsih. (2006). Manajemen Pelayanan. Yogyakarta: Pustaka Pelajar.

28. Sugiyono. (2007). Metode Penelitian Kualitatif Kuantitatif and R\&D. Bandung: Alfabeta.

29. Suharto, Edi. (2007). Kebijakan Sosial Sebagai Kebijakan Publik. Bandung: Alfabeta

30. Surat Direktur Jenderal Imigrasi Nomor: IMI.7-TI.01.02-0869 Tanggal 10 Mei 2019 tentang Pemberitahuan Penonaktifan SIMKIM Versi 1.

31. Surat Direktur Jenderal Imigrasi Nomor: IMI-UM.01.01-1958 Tanggal 08 Mei 2019 tentang Peningkatan Pelayanan Permohonan Paspor pada Kantor Imigrasi.

32. Tjiptono, Fandy and G. Chandra. (2005). Service, Quality, \& Satisfaction. Yogyakarta: Penerbit Andi.

33. Undang-Undang No. 25 Tahun 2009 tentang Pelayanan Publik.

34. Undang-Undang No. 6 Tahun 2011 tentang Keimigrasian.

35. Undang-Undang Nomor 5 Tahun 2014 tentang Aparatur Sipil Negara.

36. Wilonotomo and Koesmoyo Ponco Aji. (2018). Pelayanan Pembuatan Paspor dalam Kajiannya terhadap Teori Manfaat Teknologi Informasi. Jurnal IImiah Kebijakan Hukum. Vol. 12(2): 163-178. 